\title{
Undermined by adverse selection: Australia's Direct Action abatement subsidies
}

\section{CCEP Working Paper 1605 Apr 2016}

\section{Paul J. Burke}

Crawford School of Public Policy, The Australian National University

\section{Abstract}

This paper examines economic challenges faced by Australia's Direct Action abatement subsidy scheme. Introduced in 2014 , the scheme operates by reverse auction, funding projects voluntarily proposed by the private sector. Because the government cannot know true project counterfactuals, the lowest auction bids are likely to often be non-additional "anyway" projects. The scheme is hence likely to exhibit a systematic skew toward lowquality abatement. The paper presents a model of the adverse selection problem and describes the early experience with Direct Action. A discussion of a way forward is also provided. 


\section{Keywords:}

Abatement subsidy; adverse selection; emissions; climate; Australia

\section{JEL Classification:}

Q58; Q52; D82

\section{Suggested Citation:}

Burke, P.J. (2016), Undermined by adverse selection: Australia's Direct Action abatement subsidies, CCEP Working Paper 1605, Apr 2016. Crawford School of Public Policy, The Australian National University.

\section{Address for Correspondence:}

Paul J. Burke

Fellow

Arndt-Corden Department of Economics

The Australian National University

Coombs Building 9

Acton

ACT 2601

Australia

Tel: +61 261256566

Email: paul.j.burke@anu.edu.au

The Crawford School of Public Policy is the Australian National University's public policy school, serving and influencing Australia, Asia and the Pacific through advanced policy research, graduate and executive education, and policy impact.

The Centre for Climate Economics \& Policy is an organized research unit at the Crawford School of Public Policy, The Australian National University. The working paper series is intended to facilitate academic and policy discussion, and the views expressed in working papers are those of the authors. Contact for the Centre: Dr Frank Jotzo, frank.jotzo@anu.edu.au 


\section{Undermined by adverse selection: Australia's Direct Action abatement subsidies}

Paul J. Burke

Australian National University, ACT 2601, Australia

paul.j.burke@anu.edu.au,+61261256566

21 April 2016

This paper examines economic challenges faced by Australia's Direct Action abatement subsidy scheme. Introduced in 2014, the scheme operates by reverse auction, funding projects voluntarily proposed by the private sector. Because the government cannot know true project counterfactuals, the lowest auction bids are likely to often be non-additional "anyway" projects. The scheme is hence likely to exhibit a systematic skew toward low-quality abatement. The paper presents a model of the adverse selection problem and describes the early experience with Direct Action. A discussion of a way forward is also provided.

Running title: Direct Action abatement subsidies

Keywords: abatement subsidy; adverse selection; emissions; climate; Australia JEL classifications: Q58; Q52; D82

Acknowledgements: This paper has been informed by conversations with stakeholders and researchers. Thank you for your contributions. 


\section{Introduction}

Adverse selection occurs when an information asymmetry leads to one side of a market selfselecting in a way that exposes the other side of the market to low-quality outcomes. The concept emerged in insurance, take up of which can be dominated by those with aboveaverage exposure to risks. ${ }^{1}$ Adverse selection can occur in many other contexts, including the market for second-hand vehicles, which Akerlof (1970) famously described as being undermined by "lemons". This paper documents how adverse selection presents serious challenges for Australia's principal climate policy instrument under the Direct Action Plan ("Direct Action").

The centrepiece of Direct Action is an economy-wide abatement subsidy scheme established via amendments to the Carbon Credits (Carbon Farming Initiative) Act 2011 (Cth) (CFI Act) in $2014 .^{2}$ The scheme uses a reverse auction to allocate payments from an Emissions Reduction Fund (ERF). The process involves entities submitting sealed bids to implement registered emissions reduction projects, with the Clean Energy Regulator (CER) selecting the lowest bids per unit of notional abatement. The auction winners enter contracts with the Commonwealth Government to deliver Australian Carbon Credit Units (ACCUs), each representing a tonne of $\mathrm{CO}_{2}$-equivalent $\left(\mathrm{CO}_{2}\right.$-e) emissions reduction below an assumed baseline. Taxpayer-funded payments against these contracts occur subsequent to the delivery of the abatement. The standard crediting period is seven years.

The ERF operates alongside a mandated Renewable Energy Target (RET) that requires an increasing share of electricity to be sourced from renewable sources, as well as other policies aiming to reduce greenhouse gas emissions, such as regulations on lightbulbs. Direct Action also involves an emissions "safeguard mechanism" to discourage large emitters from increasing their emissions above historical benchmarks, due to commence on 1 July 2016. The safeguard mechanism has been set loosely and flexibly. I will focus on the abatement subsidy component of Direct Action. ${ }^{3}$

Direct Action replaced a carbon pricing regime that had been in effect from 1 July 2012 to 30 June 2014. Introduced by the former Labor government, the carbon price was initially A \$23 per tonne $\mathrm{CO}_{2}$-e. Removing the carbon price and switching to Direct Action was a key commitment of the incoming Coalition government at the 2013 election. The ERF was initially allocated $\mathrm{A} \$ 2.55$ billion of taxpayer funds over four years (Australian Government, 2014). The first two auctions were held in 2015, and the third will be in late April 2016 (subsequent to the time of writing). A review of the ERF is scheduled to commence in 2017.

The fundamental challenge for abatement subsidy schemes is their demanding information requirements. Under either a basic emissions tax or a basic emissions trading scheme (ETS),

\footnotetext{
${ }^{1}$ Rowell and Connelly (2012) report that the term "adverse selection" has been used since the $19^{\text {th }}$ Century.

${ }^{2}$ See the Climate Change Authority (2014) for a review of the CFI.

${ }^{3}$ For details on the safeguard mechanism, see http://www.environment.gov.au/climate-change/emissionsreduction-fund/about/safeguard-mechanism. My use of "baseline" will refer to baselines relevant for the ERF subsidies, not the safeguard mechanism.
} 
the government needs to know only the emissions levels of covered entities; these entities are then required to pay a tax or acquit permits for their emissions. In Australia, facility-level emissions are already measured under the National Greenhouse and Energy Reporting (NGER) scheme once reporting thresholds are exceeded. ${ }^{4}$ Under a voluntary abatement subsidy scheme applied at the project level, however, the government should ideally know two sets of information: (1) the ongoing emissions levels of participating projects, and (2) the emissions that would have been observed without the subsidy (the true baseline or counterfactual). The second of these is difficult for the government to assess. Project proponents have much better information. There is an information asymmetry.

The government's inability to know true project counterfactuals creates a major challenge. Projects with overgenerous baselines will be able to submit relatively low auction bids because the abatement they offer is largely non-additional, and thus cheap. These bids are well placed to secure funding. The scheme is thus susceptible to providing windfall informational rents to anyway projects, while delivering less abatement than notionally indicated. ${ }^{5}$

Examples of anyway projects that might be funded are:

- Capturing gas to generate electricity (when doing so may generate a profit).

- Committing to not clear land (when there was no intention to clear).

- Improving the energy efficiency of aircraft (with evolving technological possibilities).

- Updating a firm's car fleet with fuel-efficient models (to save fuel costs).

- Replacing a boiler (with one that does not leak like the current one).

- Retrofitting an industrial facility (as might be done from time to time).

- Improving a farm's soil fertility (which improves soil carbon levels).

The information asymmetry means that emissions abatement fundamentally differs from other government procurement processes. Take the purchase of a large quantity of office paper. The Commonwealth Procurement Rules require a tender, with essentially the lowestprice offer for a given quantity and quality being awarded the job. ${ }^{6}$ The system works because there is no baseline problem; there is almost no prospect of the private sector providing office paper as a free gift, so the counterfactual is clear. Emissions abatement is different because every year the private sector naturally implements projects that, on their own, happen to reduce emissions. If a reverse-auction payment scheme is available, these anyway projects are well placed to win.

While Clarke et al. (2014, p. 316-317) note that Direct Action baselines are of "fundamental importance" and that funds might be used for projects "that would have occurred anyway" and Freebairn (2014, p. 240) cautions that some funding will go to projects that would have

\footnotetext{
${ }^{4}$ See http://www.cleanenergyregulator.gov.au/NGER.

${ }^{5}$ Informational rents occur when the seller profits from knowing more than the buyer (Hanley et al., 2007).

${ }^{6}$ Small purchases can proceed using quotes rather than a formal open tender. The core rule of the

Commonwealth Procurement Rules is to achieve value for money (Department of Finance, 2014).
} 
been "undertaken anyway", Direct Action's skew toward low-quality abatement has not received the attention it deserves in the peer-reviewed literature. For example, Clarke et al. (2014) go on to use an estimate of the national marginal abatement cost curve to calculate the abatement that could be purchased under Direct Action, ignoring the key point that the scheme works on a project-by-project basis with a bias toward non-additional projects. The low-quality nature of the Direct Action purchases has received some media coverage (e.g. Edis, 2015a, 2015b; Parkinson \& Vorrath, 2015; Taylor, 2015).

The international literature provides substantial evidence on how subsidy payments for voluntary conservation activities have been subject to baseline measurement issues that lead to adverse selection (Fraser, 1995; Ferraro, 2008, 2011; Pattanayak et al., 2010; Canton et al., 2009; Arnold et al., 2013; Duke et al., 2013). Arnold et al. (2013, p. 388) conclude that reverse auctions for payments for ecosystem services can produce "an extreme adverse selection" that delivers rents to landowners paid to do what they intended to do anyway. Adverse selection is known to have compromised voluntary cash-for-clunkers schemes (Sandler, 2012), voluntary energy conservation programs (Hartman, 1988), and voluntary carbon credit schemes (van Kooten et al., 2015).

At the global level, adverse selection is widely understood to be undermining key sources of international emissions offsets, including the United Nations' Clean Development Mechanism (CDM) and Joint Implementation (JI). ${ }^{7}$ Victor (2009, p. 343) concludes "the CDM has been a disaster. Many CDM credits do not represent real reductions in emissions". The CDM has been cited as a model for Direct Action (Australian Government, 2014).

In the next section I explore the economics of abatement subsidy schemes and the adverse selection problem. Section 3 discusses the design of Direct Action, the results of the first two auctions, and other disadvantages of the scheme. Section 4 documents a need for improved textbook coverage of this issue. The final section concludes.

\section{Economics of Abatement Subsidies}

\subsection{Graphical Representation}

In this section I initially focus on the economics of firm-level schemes so as to allow a simple comparison of a tax and a subsidy. I represent a firm's emissions by $M$, abatement by $Z$, and the emissions price by $P$. The firm's demand for emissions is a negative function of price, as in Figure 1. If the price is zero, its emissions will be $\widehat{M}$. This is the baseline from which any intervention should be evaluated.

\footnotetext{
${ }^{7}$ An offset scheme is one in which firms are paid to reduce emissions (Bushnell 2012). Firms covered by an emissions tax or an ETS could be allowed to use voluntary offsets generated outside the scheme to reduce their tax/permit liabilities. On adverse selection in international offset schemes, see Richards and Andersson (2001), Fischer (2005), Wara (2008), Schneider (2009), Victor (2009), Millard-Ball and Ortolano (2010), Kerr and Millard-Ball (2012), Richards and Huebner (2012a), Strand and Rosendahl (2012), Hahn and Richards (2013), He and Morse (2013), Millard-Ball (2013), van Benthem \& Kerr (2013), and Schneider and Kollmuss (2015).
} 


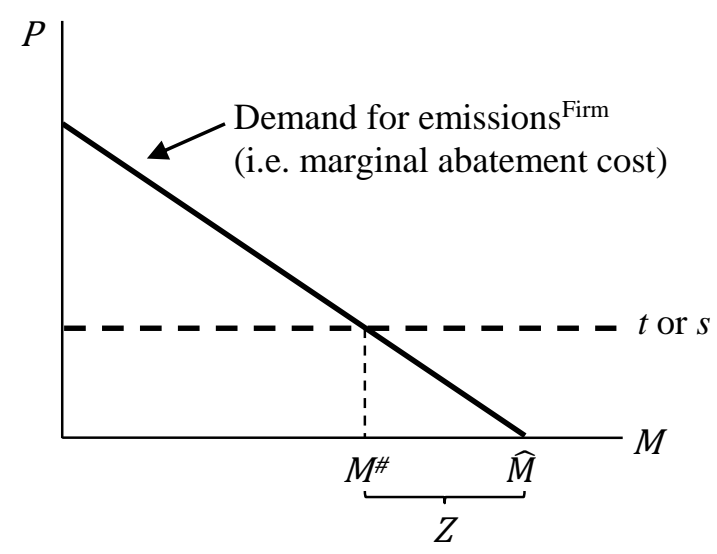

Figure 1. Firm-level analysis of a per-unit tax or per-unit subsidy.

The introduction of a per-unit emissions tax $(t)$ or per-unit abatement subsidy $(s)$ increases the cost of emitting and so should induce a reduction in emissions. If $t=s$, there are no implementation or participation costs, firms are profit-maximising, and both firms and the government have complete information, then either approach will induce the same emissions reduction ("abatement") in the short run, with the firm now choosing to emit $M^{\#}$. The quantity of abatement is $Z=\widehat{M}-M^{\#}$. Short-run equivalence between the tax and subsidy occurs because the marginal cost of emitting is the same under either policy: the firm needs to pay the per-unit tax or forgo the per-unit subsidy.

The most attractive feature of the simple tax/subsidy approach is that the intervention can induce abatement at least cost. Emissions from $M^{\#}$ to $\widehat{M}$ are the firm's least valuable, as its willingness to pay (= marginal abatement cost) is the lowest. These "low hanging fruit" coincide with the emissions that will be abated.

Figure 1 also reveals the main shortcoming of an abatement subsidy scheme. The information required for the government to implement the emissions tax is only $M^{\#}$, the firm's observed post-tax emissions level. The information required for the subsidy scheme is larger: the government needs to know $M^{\#}$ (the post-subsidy emissions level) and also $\widehat{M}$ (the baseline emissions level) to be able to provide the subsidy for units $\widehat{M}-M^{\#} . \widehat{M}$ is unobservable; if the abatement subsidy is being paid, it is an outcome that does not actually happen. ${ }^{8}$

Estimating $\widehat{M}$ using data from before a subsidy scheme starts is typically inadequate. Changes in technology and the economy lead to shifts in emissions demand curves. Firms in sunrise sectors may have increasing demand to emit, while firms in sunset sectors may have declining demand. Commodity producers have a demand linked to (difficult-to-forecast) international markets. Opportunities for energy efficiency improvements arise in a manner that is hard to anticipate. It is often difficult to accurately predict $\widehat{M}$.

\footnotetext{
${ }^{8}$ Baumol and Oates (1988) show that an abatement subsidy scheme can be considered to consist of (a) a tax on emissions at rate $t$, and (b) a lump-sum abatement payment of $s \widehat{M}$. If so, errors in the estimation of $\widehat{M}$ will not have any direct emissions implication. This representation does not apply to an opt-in abatement subsidy scheme with no functional tax.
} 


\subsection{Mathematical Representation}

To demonstrate the potential for adverse selection in voluntary abatement subsidy schemes, I represent the emissions demand of firm $i$ during year $t$ as:

$$
M_{i, t}=a_{i, t}-b_{i, t} P_{i, t}
$$

where $M, a, b, P \geq 0$, and $a$ and $b$ are parameters. Each firm faces a separate emissions price, as in a reverse auction. The use of a linear emissions demand function simplifies the maths. Assume the government does not know Eq. (1) but has annual data on firm-level emissions, as is the case in Australia for large emitters under the NGER scheme.

When $P_{i, t}=0, \widehat{M}_{i, t}=a_{i, t}$. This is the true baseline/counterfactual. The government is unaware of this level in year $t$, as it does not know Eq. (1). I will use $X$ to refer to the government's estimate of $\widehat{M}$, the emissions level from which an abatement subsidy would apply. For some firms, we are likely to have $X_{i, t}>\widehat{M}_{i, t}$ (baseline overestimated). For others, $X_{i, t}<\widehat{M}_{i, t}$ (baseline underestimated). In some instances, we could have $X_{i, t}=\widehat{M}_{i, t}$.

If there is a voluntary abatement subsidy available at a per-unit rate of $s_{i, t}(\geq 0)$, then in the absence of participation costs each firm faces the following decision:

$$
\begin{aligned}
& \max \{\text { not participate; participate }\} \\
& =\max \{\text { payoff }=0 ; \text { payoff }=\text { subsidy payment }- \text { abatement cost }\}
\end{aligned}
$$

If a firm participates and is able to receive the abatement subsidy for as many units of abatement as it wishes, the total subsidy payment it receives will be:

$$
\begin{aligned}
& s_{t} *\left(X_{i, t}-M_{i, t}^{\#}\right) \\
& =s_{t} *\left(X_{i, t}-a_{i, t}+b_{i, t} s_{i, t}\right)
\end{aligned}
$$

and the firm's abatement will equal:

$$
Z_{i, t}=\widehat{M}_{i, t}-M_{i, t}^{\#}=b_{i, t} s_{i, t}
$$

The marginal abatement cost (MAC) is the inverse abatement supply function:

$$
\mathrm{MAC}_{i, t}=b_{i, t}{ }^{-1} Z_{i, t}
$$

Integrating with respect to $Z_{i, t}$ provides the abatement cost (AC):

$$
\mathrm{AC}_{i, t}=\left(2 b_{i, t}\right)^{-1} Z_{i, t}^{2}
$$

Note that $X_{i, t}$ is irrelevant to the true cost of abatement.

Continuing to assume no participation costs, ${ }^{9}$ each firm will participate and deliver the abatement associated with $s_{i, t}$ if:

\footnotetext{
${ }^{9}$ In practice, firms will also need to incorporate participation costs into their bids. I have excluded participation costs to provide a simple demonstration of the importance of baselines and a direct comparison with a tax. It
} 
subsidy payment - abatement cost $>0$

$s_{i, t} *\left(X_{i, t}-a_{i, t}+b_{i, t} s_{i, t}\right)-\left(2 b_{i, t}\right)^{-1}\left(b_{i, t} s_{i, t}\right)^{2}>0$

$s_{i, t}>2 b_{i, t}^{-1}\left(\widehat{M}_{i, t}-X_{i, t}\right)$

Firms with $\widehat{M}_{i, t}>X_{i, t}$ will need a relatively high $s_{i, t}$ to make participation in the scheme worthwhile. These firms will find it difficult to be competitive in a reverse auction; they might well not register in the first place. Firms with $\widehat{M}_{i, t} \leq X_{i, t}$ will be keen to participate at any positive per-unit subsidy rate, offering more abatement when $s_{i, t}$ is higher. For $X_{i, t}-$ $\widehat{M}_{i, t}$ units, the subsidy will be purely windfall in nature.

In the context of a reverse auction, firms with $\widehat{M}_{i, t}<X_{i, t}$ are in the best position to submit competitive bids for a project of a certain minimum scale given that they face no costs for $X_{i, t}-\widehat{M}_{i, t}$ units. Competitive bids win reverse auctions. This is thus a market that is susceptible to adverse selection. The greater the number of firms with generous baselines, the more serious the adverse selection.

Adverse selection means that there is likely to be a distinction between the true abatement provided by an abatement subsidy scheme and announced quantities. If the reverse auction is won by $N$ firms, then:

$$
\begin{aligned}
& \text { Abatement }{ }_{t}^{\text {True }}=\sum_{i=1}^{N} b_{i, t} s_{i, t} \\
& \text { Abatement }^{\text {Government's understanding }}{ }_{t}=\sum_{i=1}^{N}\left(X_{i, t}-\widehat{M}_{i, t}+b_{i, t} s_{i, t}\right)
\end{aligned}
$$

Information asymmetry and adverse selection mean that $X_{i, t}-\widehat{M}_{i, t}$ will likely exceed zero for many or all of the winning firms, a problem likely to be exacerbated by a behind-the scenes incentive for the operator of the scheme to allow generous baselines (Millard-Ball, 2013). Announced abatement achievements are thus likely to be overestimates.

Assuming offsets are disallowed, adverse selection does not affect either an emissions tax or an ETS; a per-unit tax or permit price of $\tau_{t}$ will induce abatement of $b_{i, t} \tau_{t}$ across all covered firms. Least-cost abatement will be achieved even if emissions demand curves change in an unpredictable way on a year-to-year basis.

\subsection{Three Project Types}

Turning to the project level, Figure 2 shows true and "government-estimated" emissions baselines for three types of projects: those for which the government has an accurate estimate of the emissions baseline into the future; those for which the baseline is overgenerous; and those for which the baseline is underestimated.

would be possible to model alternative abatement cost functions, such as one for lumpy projects. Eq. (7) is a standard-form, differentiable representation. 
The adverse selection process is not one in which baseline errors are averaged out. Instead, there is a natural push for projects of Type B to dominate, irrespective of whether baseline errors are random or systematic. Intermediaries will reinforce the process as they have an incentive to identify non-additional projects. ${ }^{10}$ A push toward projects of Type B means that (a) the scheme will have a skew to non-additional abatement, and (b) low-cost abatement opportunities from other potential projects (Types A and C) will be missed. Instead of a market in abatement, we may end up with a market dominated by anyway projects.

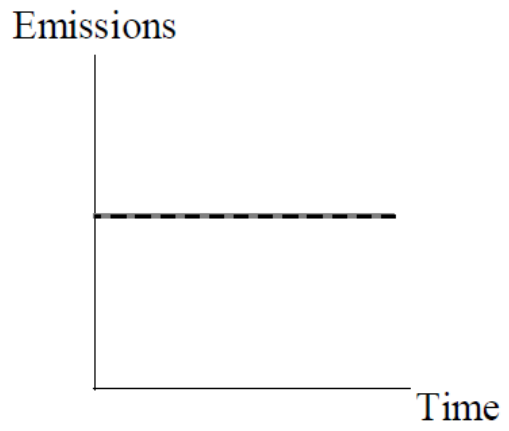

Type A: Baseline correct

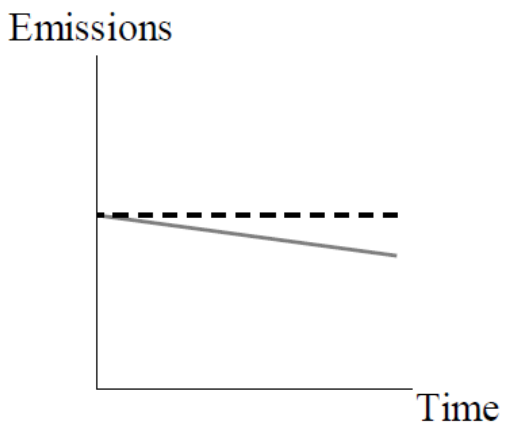

Type B: Baseline overestimated

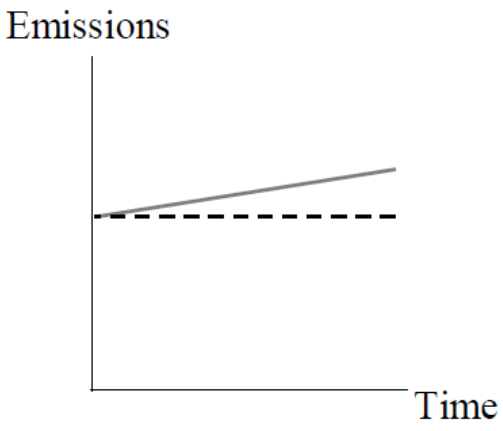

Type C: Baseline underestimated

$$
\text { ----- Government's estimate of baseline — True baseline }
$$

Figure 2. The three types of projects competing in a reverse auction for abatement subsidies. Projects of Type B can submit low auction bids and dominate the auction winners list, but the abatement they offer is partly or fully non-additional ("anyway"). Projects of Type A and particularly $\mathrm{C}$ will find it difficult to compete, meaning that low-cost abatement opportunities from these projects may be missed. The point applies (a) for alternative baseline shapes (e.g. a declining baseline), and (b) at the facility and firm levels also. Time $=0$ is the project start date.

\section{Direct Action}

I now turn to the specifics of Direct Action's design and describe the results of the first two auctions. I then discuss other disadvantages of Direct Action.

\subsection{Design}

The ERF White Paper (Australian Government, 2014) does not mention "adverse selection" or "information asymmetry". While it does discuss the need to ensure abatement is genuine, a rather relaxed definition of additionality has been adopted. Specifically, the document states that a "flexible approach to additionality" (p. 69) will be used "that minimises the costs to businesses and encourages participation" (p. 22). Private co-benefits are emphasised (p. 7), but the difficulty is that projects that provide private benefits may well be pursued anyway.

Section 27 of the CFI Act lists three additionality requirements:

\footnotetext{
${ }^{10}$ One intermediary has publically advised potential participants that the ERF should often be seen as "an additional revenue stream for projects that are going ahead for other reasons".
} 
1) Newness: The project must not have already been implemented.

2) Regulatory additionality: The project must not be required under law.

3) Government program requirement: The project must not be likely to be carried out under another government program.

Across the Australian economy, new projects are launched every year, so the newness requirement does not rule out anyway projects. Unlike the CDM, no test of financial additionality is being applied, for the good reason that such tests are resource-intensive and easily manipulated. Projects developed under the former CFI have received an exemption from the newness requirement.

The ERF's process for defining projects and measuring project-by-project abatement uses methods developed by the Department of the Environment. ${ }^{11}$ The methods are legislative instruments. While the "common practice" test under the former CFI has been scrapped, the offsets integrity standards under Section 133 of the CFI Act state that the methods "should result in carbon abatement that is unlikely to occur in the ordinary course of events". As discussed, the ordinary course of events is often difficult for the government to identify in a dynamic economy. There are separate methods for individual activities, as well as a general facility-wide method. 33 methods had been approved as of mid-April 2016. An Emissions Reductions Assurance Committee considers draft methods and provides advice to the Minister.

The methods generally use recent emissions or emissions intensity averages to form project baselines. Some allow for declining baselines over time; the land and sea transport method, for example, uses declining emissions intensity baselines for some vehicle categories in recognition of ongoing improvements in vehicle fuel economy. Some have more rigorous approaches to additionality than others; the "aggregated small energy users" method requires a randomised control trial, for instance. Projects that are required to use more demanding methods will find it difficult to be Type B (Figure 2) and will also face higher participation costs. They will be less likely to participate.

The methods are detailed, complicated, and reflect considerable effort on the government's behalf. There is a method for projects that reduce the emissions intensity of beef production by productivity-enhancing steps such as increasing a herd's weight:age ratio, reducing its average age, or reducing the share of unproductive animals. The land and sea transport method covers the purchase of efficient vehicles, use of bio-fuels, fitting of low-resistance tyres, and other actions. The aviation method covers fuel-saving steps such as replacing aircraft parts with lighter alternatives. And so on. There are private incentives for these activities. While the methods do exclude many types of bogus project ideas, they thus also leave ample opportunity for anyway projects.

${ }^{11}$ See https://www.environment.gov.au/climate-change/emissions-reduction-fund/methods. 
Direct Action's adverse selection problem is exacerbated by the ability of project proponents to influence their own baseline. It is the proponent's responsibility to identify their baseline in accordance with approved methods, and there is some flexibility. For example, a proponent could apply an activity method or the facilities method, or choose between a method relying on direct measurement or one using model-based defaults (e.g. for soil carbon). Project proponents should be expected to define their abatement as favourably as possible.

Participants whose projects underperform in the implementation phase are allowed to purchase ACCUs from other registered projects and then deliver these to the government under make-good provisions (Australian Government, 2014). If non-additional projects are credited with ACCUs, a behind-the-scenes dynamic for anyway projects thus continues well after any ERF auction, from projects that did not even receive an ERF contract. Project underperformance is a real risk: the Australian National Audit Office (ANAO, 2010) reported that projects funded by the Greenhouse Gas Abatement Program (GGAP) delivered "substantially less than originally planned" (p. 17). GGAP was a federal grants scheme for initiatives to reduce emissions - a precursor to Direct Action.

\subsection{The first two auctions}

The first ERF auction, in April 2015, saw 43 participants receive abatement contracts for a total of 144 projects, with an average price per tonne $\mathrm{CO}_{2}$-e of $\mathrm{A} \$ 13.95$ and a total commitment of A $\$ 660.5$ million. Awarded contracts cover 47.3 million tonnes of notional abatement, with lengths ranging three to 10 years.

Almost $60 \%$ of the abatement purchased in the first auction was from avoided deforestation projects centred on Cobar and Bourke in New South Wales, awarded to leaseholders with permits to clear invasive native species ("woody weeds"). Only permits predating 1 July 2010 are eligible. Large sums of money - often many times the value of the land (Taylor, 2015) have been awarded for projects involving little effort. The payments rest on the assumption that clearing would have happened without the subsidy. Given the size of the payments, it seems likely that some vegetation has indeed been preserved, albeit at a high price. Some of the spending has questionable additionality, however, given that the incentive to clear was anyway rather low (clearing is expensive and the productivity of the land is low) and that there is an incentive to identify the most marginal land to offer up to the scheme. In my discussions with local stakeholders, Direct Action revenue was referred to as "cream" and "too good to be true".

Most of the remainder of the payments in the first auction went to landfill gas projects. Like the avoided deforestation projects, these are also carryovers from the former CFI. Many have been running for years, with the operators using the gas to generate revenue from (a) electricity production, and (b) renewable energy certificates under the RET (Cannane \& Andersen, 2015; Edis, 2015b). Many have a private incentive to operate.

The second ERF auction was held in November 2015. The government signed 129 contracts worth a total of $\mathrm{A} \$ 557$ million, for 45.45 million tonnes of $\mathrm{CO}_{2}$-e abatement. The average 
price was $\mathrm{A} \$ 12.25$ per tonne. $56 \%$ of the contracted abatement was from vegetation projects, $15 \%$ from altering savanna fire management, $9 \%$ from agriculture, and the remainder from energy efficiency projects, landfill and waste, transport, and industrial fugitives. One project received funding to upgrade lighting in supermarkets; another to increase the fuel efficiency of vehicles and marine vessels; another to use piggery gas to generate electricity. There are private benefits to these projects. They are the type of activities that are supposed to occur in a market economy.

ACCUs could be used as offsets under the former carbon pricing scheme, as well as in the voluntary market, with most early-vintage ACCUs coming from the waste sector (Climate Change Authority, 2014). Questions over the additionality of ACCUs pre-date the ERF. RepuTex (2014), for example, concluded:

\section{"Almost all current ACCU generating projects ... have alternative revenue streams that can independently finance a project payback of less than 3 years. As a result, the main economic driver of nearly all existing projects is the desire to reduce energy bills and/or sell energy to another party, with the revenue from ACCUs most often treated as a bonus" (p. 5)}

\subsection{Other disadvantages}

In addition to the adverse selection of non-additional abatement, there are numerous other disadvantages of the Direct Action subsidy approach (Jotzo \& Burke, 2014). The first is that considerable administrative effort is required on behalf of the government in developing methods and judging and monitoring individual abatement projects. Project proponents also face substantial participation costs, including costs related to understanding the complicated ERF methods.

Another is that many low-hanging abatement opportunities will be missed. ERF projects must be of a minimum scale (2,000 tonnes of $\mathrm{CO}_{2}$-e per year), and while the aggregation of smallscale initiatives into a single ERF project is allowed, paperwork and monitoring requirements mean that some actions may never be able to receive funding under the scheme. How could a contract be properly enforced to incentivise cycling to work once a week, for instance? A broad-based carbon price incentivises such actions; subsidy contracts would be unworkable (Freebairn, 2014). As discussed, projects that do not receive favourable treatment from the ERF's methods will find it difficult to be competitive in the reverse auctions.

The electricity sector, which accounts for around one-third of Australia's greenhouse gas emissions, is a particular weak-spot for Direct Action. It is fundamentally challenging for an abatement subsidy scheme to incentivise reductions across an electricity generation system, as reductions from any single facility may be directly replaced by increases from others ("leakage"). As is, the facilities method (the method that may be used by electricity generators) is restricted to projects that reduce a facility's emissions intensity rather than its emissions. Electricity-sector emissions declined by $9 \%$ over the two years of the carbon price and have increased since its removal (Figure 3). While there are many factors affecting 
electricity-sector emissions in any single year, it is fair to conclude that the carbon price provided an incentive for emissions reductions in the electricity sector that Direct Action is not providing.

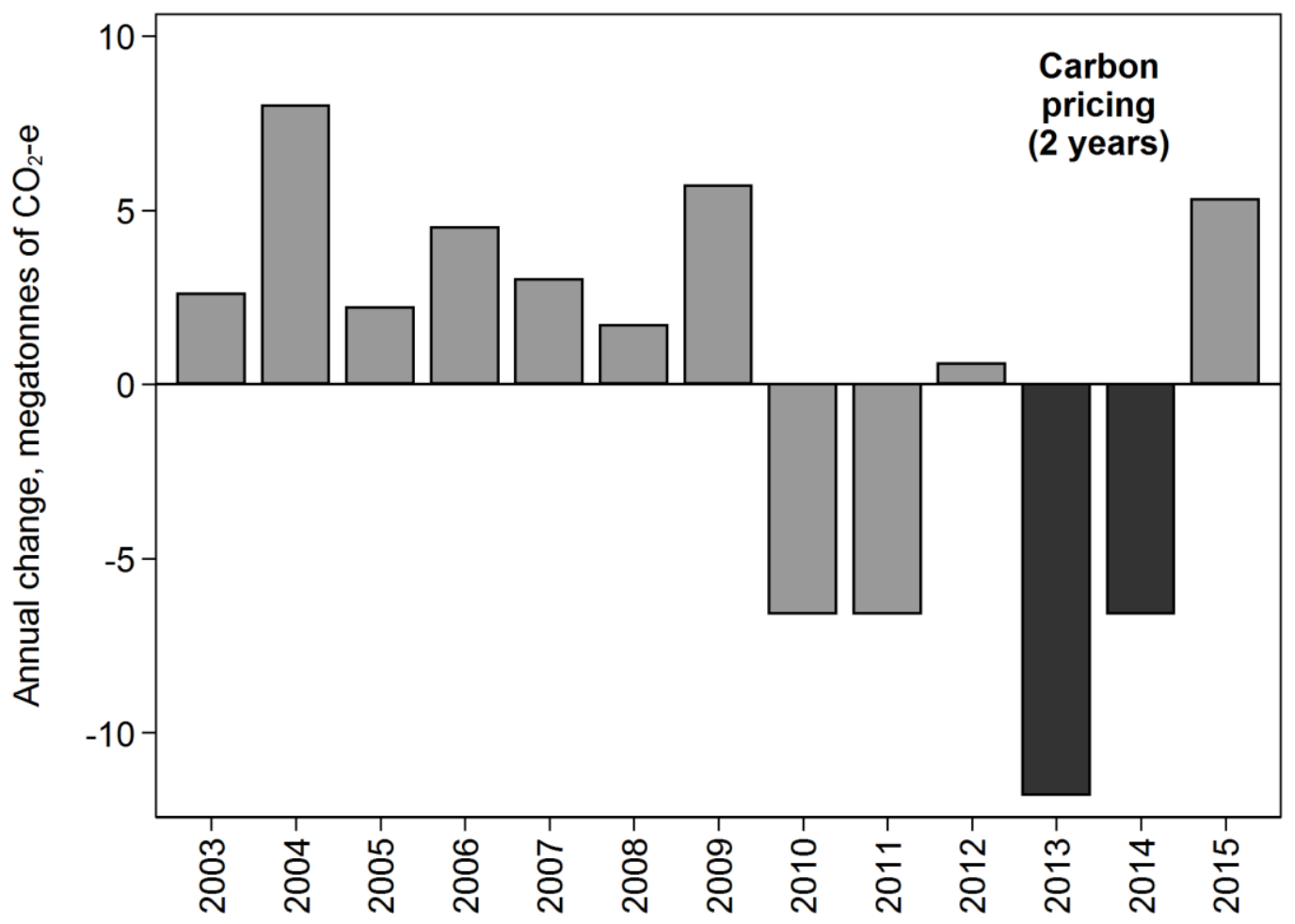

Figure 3. Changes in Australia's electricity-sector emissions, by fiscal year.

Source: Department of the Environment $(2015,2016)$. Data are for unadjusted emissions. The carbon price was applied for fiscal years 2012-2013 and 2013-2014.

The risk of emissions leakage is a concern outside the electricity sector also. Abated emissions might simply reappear elsewhere (Chomitz, 2002; Richards \& Huebner, 2012b; Kerr \& Millard-Ball, 2012). One example is farmers using Direct Action payments to fund tree clearing on other properties. Some projects might even cause a net increase in emissions. The ERF's design does not have a strong focus on preventing leakage: the CFI Act, ERF White Paper, and key methods (e.g. the facilities method) do not mention the term. While section 133 of the CFI Act requires deductions for emissions that are "a direct consequence of carrying out the project" and "material" in scale, this does not extend to indirect leakage. The full extent of emissions leakage is typically difficult to measure.

Another downside to Direct Action is that subsidies are funded by taxes, which cause distortion costs to the economy. An emissions tax or ETS, on the other hand, could be used to replace distorting taxes and play a role in broader tax reform. Direct Action is exacerbating Australia's budget deficit; carbon revenue could be reducing it.

Direct Action has also introduced some undesirable incentives. Firms have an incentive to delay emissions-reducing projects until they are registered with the CER. State and territory governments have an incentive to avoid initiatives that reduce emissions so as to not 
disqualify projects from the ERF. Such schemes also risk instilling a culture of subsidies and government involvement in project selection.

Finally, the cost ineffectiveness resulting from anyway projects can be exacerbated when there is a strong expectation of what the highest funded price will be. ${ }^{12}$ The reason for this is that it can be an attractive strategy to build a healthy rent margin into reverse auction bids. A repeated auction format, as used for Direct Action, is particularly prone to overpriced bids, as unsuccessful project proponents can expect to re-bid in future auction rounds.

\section{Textbook Coverage}

Textbooks in environmental economics often demonstrate the potential short-run equivalence between emissions taxes and abatement subsidies, but most do not adequately convey the point that abatement subsidy schemes can be undermined by information asymmetry problems. Table 1 details how 17 environmental economics textbooks cover abatement subsidy schemes. Hanley et al. (2007) provide the most comprehensive coverage.

\section{Conclusion}

Australia's Direct Action abatement subsidies provide an example of an environmental intervention vulnerable to adverse selection. The key disadvantage of the scheme is that it funds individual projects in a context in which it is difficult to determine if they would have happened anyway. The cost advantage of anyway projects means that they are well placed to win the ERF auctions. The experience to date suggests that this issue is a real concern and that there are indeed opportunities for anyway projects to receive windfall rents. The purpose of a reverse auction is to minimise procurement costs, but reverse auctions can be costineffective when adverse selection occurs and purchased abatement is actually nonadditional. The main lesson from the Direct Action experience is that it is preferable to design schemes that do not rely on difficult-to-observe information such as counterfactual project baselines. Direct Action has extended the additionality concerns surrounding the former CFI to an economy-wide basis.

One way to reform the current arrangements is to tighten Direct Action's safeguard mechanism and operate it as a baseline-and-credit scheme without government subsidies. There are many design decisions for such a scheme, including whether to use absolute or emissions-intensity baselines (Wood et al., 2016). A baseline-and-credit scheme would be an improvement over the current subsidy approach, although it should be kept in mind that a share of permits traded will be anyway in nature, generated by firms that happen to be below their government-determined baseline. ${ }^{13}$ A baseline-and-credit scheme is also likely to have higher administrative and lobbying costs than a standard ETS, provide less certainty over the

\footnotetext{
12 The CER sets a secret benchmark price and then chooses a percentage of bids below this level, subject to the ERF budget (Australian Government, 2014).

${ }^{13}$ See MacGill et al. (2006) and Passey et al. (2008) for discussions of earlier baseline-and-credit schemes such as the New South Wales Greenhouse Gas Reduction Scheme. See Maron et al. (2015) for a discussion of issues related to baseline setting in biodiversity offsetting schemes.
} 
achievement of an emissions target, and miss out on revenue that could be used to reduce Australia's budget deficit or for other purposes. A standard ETS would hence be preferable.

An emissions tax is in several respects even more attractive than an ETS: it is administratively simpler, trading costs can be avoided, and price uncertainty minimised. Australia's recent climate policy history suggests that an ETS is likely to be more politically viable than an emissions tax, however. In some sectors - such as landfill, coal mining, and avoided deforestation - well-designed and enforced regulatory approaches are also an option.

Considerable work has gone into developing the ERF project methods. For emissions already covered by the NGER scheme this work is superfluous to Australia's long-term requirements given that policy alternatives exist that avoid the adverse selection problem. Several of the other methods may be of long-term use for measuring emissions offsets. If Australia is to return to either an emissions tax or ETS, the issue of adverse selection means that care will be needed in the design of any offset arrangements. 
Table 1. Coverage of abatement subsidies by textbooks in environmental economics.

\begin{tabular}{|c|c|c|c|c|c|}
\hline Textbook & $\begin{array}{l}\text { Coverage of } \\
\text { economics of } \\
\text { abatement } \\
\text { subsides? }\end{array}$ & $\begin{array}{l}\text { Coverage of potential } \\
\text { short-run equivalence } \\
\text { of compulsory } \\
\text { abatement subsidy and } \\
\text { emissions tax? }\end{array}$ & $\begin{array}{l}\text { Mention of difficulty of } \\
\text { estimating baselines } \\
\text { for abatement subsidy } \\
\text { scheme? }\end{array}$ & $\begin{array}{l}\text { Mention of adverse } \\
\text { selection / low-quality } \\
\text { abatement occurring } \\
\text { under an abatement } \\
\text { subsidy scheme? }\end{array}$ & $\begin{array}{l}\text { "Adverse } \\
\text { selection" } \\
\text { listed in } \\
\text { index? }\end{array}$ \\
\hline Hanley et al. (2007) ${ }^{\mathrm{a}}$ & Yes & Yes & Yes & Yes & Yes \\
\hline Kolstad $(2011)^{b}$ & Yes & Yes & No & No & Yes \\
\hline Perman et al. $(2011)^{\mathrm{c}}$ & Yes & Yes & Yes & No & No \\
\hline Callan and Thomas (2013) & Yes & Yes & No & No & No \\
\hline Field and Field (2013) & Yes & Yes & No & No & No \\
\hline Grafton et al. $(2004)^{\mathrm{d}}$ & Yes & Yes & No & No & No \\
\hline Asafu-Adjaye (2005) & Yes & Yes & No & No & No \\
\hline Anderson $(2014)^{\mathrm{e}}$ & Yes & No & No & No & No \\
\hline Hanley et al. (2013) & No & No & No & No & Yes \\
\hline Siebert (2008) & Yes & No & No & No & No \\
\hline Tisdell (2005) & Yes & No & No & No & No \\
\hline Cato $(2011)^{\mathrm{f}}$ & No & No & No & No & No \\
\hline Gilpin $(2000)^{\mathrm{g}}$ & No & No & No & No & No \\
\hline Hussen (2013) & No & No & No & No & No \\
\hline Thampapillai and Sinden $(2013)^{\mathrm{h}}$ & No & No & No & No & No \\
\hline Tietenberg and Lewis (2012) & No & No & No & No & No \\
\hline Wills (2006) & No & No & No & No & No \\
\hline
\end{tabular}

Notes: Covers a sample (cf. census) of textbooks. Ranked from the most to the least instances of "Yes", then alphabetically by first author's surname.

a: See pp. 100-104 for a discussion of the information challenges associated with abatement subsidy schemes.

b: Provides good coverage of information problems, including in Chapter 15 ("Regulation with unknown control costs") and Chapter 16 (“Audits, enforcement, and moral hazard"), but without a discussion of adverse selection undermining abatement subsidy schemes.

c: There is a brief mention of the information asymmetry on p. 200: "a firm has an incentive to misrepresent the uncontrolled level of emissions in order to obtain a favourable benchmark in terms of which the subsidy payments are calculated". A discussion of additionality problems in offset schemes is also provided on p. 210.

d: The need for information is mentioned ("with perfect information it is theoretically possible to set the baseline emissions", p. 77), but the difficulty of obtaining information on baseline emissions is not.

e: pp. 81-82 cover subsidies for positive externalities.

f: Only briefly mentions abatement subsidies and that they are "similar to taxes in concept" (p. 125)

g: pp. $150-152$ provide only a general discussion of environmentally-related subsidies.

h. The short discussion on p. 222 does not cover the economics. 


\section{References}

Akerlof, G.A. (1970), 'The market for "lemons": Quality uncertainty and the market mechanism', Quarterly Journal of Economics, 84(3), 488-500.

Anderson, D.A. (2014), Environmental Economics and Natural Resource Management. 4th Edition. Routledge, New York.

Arnold, M.A., Duke, J.M. and Messer, K.D. (2013), 'Adverse selection in reverse auctions for ecosystem services', Land Economics, 89(3), 387-412.

Asafu-Adjaye, J. (2005), Environmental Economics for Non-Economists: Techniques and Policies for Sustainable Development. World Scientific, Singapore.

Australian Government (2014), Emissions Reduction Fund White Paper. Commonwealth of Australia, Canberra.

Australian National Audit Office (2010), Administration of Climate Change Programs, Audit Report No. 26 2009-10, Canberra.

Baumol, W.J. and Oates, W.E. (1988), The Theory of Environmental Policy. $2^{\text {nd }}$ Edition. Cambridge University Press, Cambridge, UK.

Bushnell, J.B. (2012), 'The economics of carbon offsets', in Fullerton, F., Wolfram, C. The Design and Implementation of U.S. Climate Policy. University of Chicago Press, Chicago, 197-209.

Callan, S.J. and Thomas, J.M. (2013), Environmental Economics \& Management: Theory, Policy, and Applications. $6^{\text {th }}$ Edition. South-Western, Mason, $\mathrm{OH}$.

Cannane, S. and Andersen, B. (2015), 'Concerns raised after Federal Government awards millions of dollars to old emissions reduction projects', $A B C$ News, 28 May, http://www.abc.net.au/news/2015-05-27/carbon-abatement-auction-goverment-awardsmillions-old-projects/6500716.

Canton, J., De Cara, S. and Jayet, P.A. (2009), 'Agri-environmental schemes: Adverse selection, information structure and delegation', Ecological Economics, 68, 2114-2121.

Cato, M.S. (2011), Environment and Economy. Routledge, London and New York.

Chomitz, K.M. (2002), 'Baseline, leakage and measurement issues: How do forestry and energy projects compare?', Climate Policy, 2(1), 35-49.

Clarke, H., Fraser, I. and Waschik, R.G. (2014), 'How much abatement will Australia's Emissions Reduction Fund buy?', Economic Papers, 33(4), 315-326.

Climate Change Authority (2014), Carbon Farming Initiative Review. Commonwealth of Australia, Melbourne.

Department of Finance (2014), Commonwealth Procurement Rules. Commonwealth of Australia, Canberra. 
Department of the Environment (2015), Quarterly Update of Australia's National Greenhouse Gas Inventory: March 2015. Commonwealth of Australia, Canberra.

Department of the Environment (2016), Quarterly Update of Australia's National Greenhouse Gas Inventory: September 2015. Commonwealth of Australia, Canberra.

Duke, J.M., Dundas, S.J. and Messer, K.D. (2013), 'Cost-effective conservation planning: Lessons from economics', Journal of Environmental Management, 125, 126-133.

Edis, T. (2015a), 'The stunning mediocrity of Minister Hunt's abatement auction', Climate Spectator, 27 April, http://www.businessspectator.com.au/article/2015/4/27/policypolitics/stunning-mediocrity-minister-hunts-abatement-auction.

Edis, T. (2015b), 'Why the Direct Action auction has a suspicious whiff of rubbish abatement', Climate Spectator, 27 May,

http://www.businessspectator.com.au/article/2015/5/27/carbon-markets/why-direct-actionauction-has-suspicious-whiff-rubbish-abatement.

Ferraro, P.J. (2008), 'Asymmetric information and contract design for payments for environmental services', Ecological Economics, 65, 810-821.

Ferraro, P.J. (2011), 'The future of payments for environmental services', Conservation Biology, 25(6), 1134-1138.

Field, B.C. and Field, M.K. (2013), Environmental Economics. $6^{\text {th }}$ Edition. McGraw-Hill Irwin, New York.

Fischer, C. (2005), 'Project-based mechanisms for emissions reductions: Balancing trade-offs with baselines', Energy Policy, 33, 1807-1823.

Fraser, I.M. (1995), 'An analysis of management agreement bargaining under asymmetric information', Journal of Agricultural Economics, 46(1), 20-32.

Freebairn, J. (2014), 'Carbon price versus subsidies to reduce greenhouse gas emissions', Economic Papers, 33(3), 233-242.

Gilpin, A. (2000), Environmental Economics: A Critical Overview. John Wiley \& Sons, Chichester, UK.

Grafton, R.Q., Adamowicz, W., Dupont, D., Nelson, H., Hill, R.J. and Renzetti, S. (2004), The Economics of the Environment and Natural Resources. Blackwell, Malden, MA.

Hahn, R. and Richards, K. (2013), 'Understanding the effectiveness of environmental offset policies', Journal of Regulatory Economics, 44(1), 103-119.

Hanley, N., Shogren, J.F. and White, B. (2007), Environmental Economics in Theory and Practice. $2^{\text {nd }}$ Edition. Palgrave Macmillan, Basingstoke, UK. 
Hanley, N., Shogren, J.F. and White, B. (2013), Introduction to Environmental Economics. $2^{\text {nd }}$ Edition. Oxford University Press, Oxford, UK.

Hartman, R.S. (1988), 'Self-selection bias in the evolution of voluntary energy conservation programs', Review of Economics and Statistics, 70(3), 448-458.

He, G. and Morse, R. (2013), 'Addressing carbon Offsetters' Paradox: Lessons from Chinese wind CDM', Energy Policy, 63, 1051-1055.

Hussen, A. (2013), Principles of Environmental Economics and Sustainability: An Integrated Economic and Ecological Approach. $3^{\text {rd }}$ Edition. Routledge, New York.

Jotzo, F. and Burke, P. (2014), 'Direct Action: Wrong way, go back', Inside Story, http://insidestory.org.au/direct-action-subsidies-wrong-way-go-back.

Kerr, S. and Millard-Ball, A. (2012), 'Cooperation to reduce developing country emissions', Climate Change Economics, 3(4), 30 pages.

Kolstad, C.D. (2011), Environmental Economics. $2^{\text {nd }}$ Edition. Oxford University Press, New York.

MacGill, I., Outred, H. and Nolles, K. (2006), 'Some design lessons from market-based greenhouse gas regulation in the restructured Australian electricity industry', Energy Policy, 34(1), 11-25.

Maron, M., Bull, J.W., Evans, M.C. and Gordon, A. (2015), 'Locking in loss: Baselines of decline in Australian biodiversity offset policies', Biological Conservation, 192, 504-512.

Millard-Ball, A. (2013), 'The trouble with voluntary emissions trading: Uncertainty and adverse selection in sectoral crediting programs', Journal of Environmental Economics and Management, 65, 40-55.

Millard-Ball, A. and Ortolano, L. (2010), 'Constructing carbon offsets: The obstacles to quantifying emission reductions', Energy Policy, 38(1), 533-546.

Parkinson, G. and Vorrath, S. (2015), 'Australia's big fail on climate and energy policies', REneweconomy, http://reneweconomy.com.au/2015/australias-big-fail-on-climate-andenergy-policies-68925.

Passey, R., MacGill, I., Outhred, H. (2008), 'The governance challenge for implementing effective market-based climate policies: A case study of The New South Wales Greenhouse Gas Reduction Scheme', Energy Policy, 36(8), 3009-3018.

Pattanayak, S.K., Wunder, S. and Ferraro, P.J. (2010), 'Show me the money: Do payments supply environmental services in developing countries?', Review of Environmental Economics and Policy, 4(2), 254-274.

Perman, R., Ma, Y., Common, M., Maddison, D. and McGilvray, J. (2011), Natural Resource and Environmental Economics. $4^{\text {th }}$ Edition. Addison Wesley, Harlow, UK. 
RepuTex (2014), Unlocking Land Sector Abatement: Outlook for the Emissions Reduction Fund, January.

Richards, K. and Andersson, K. (2001), 'The leaky sink: persistent obstacles to a forest carbon sequestration program based on individual projects', Climate Policy, 1(1), 41-54.

Richards, K.R. and Huebner, G.E. (2012a), 'Evaluating protocols and standards for forest carbon-offset programs, Part A: Additionality, baselines and permanence', Carbon Management, 3(4), 393-410.

Richards, K.R. and Huebner, G.E. (2012b), 'Evaluating protocols and standards for forest carbon-offset programs, Part B: Leakage assessment, wood products, validation and verification', Carbon Management, 3(4), 411-425.

Rowell, D. and Connelly, L.B. (2012), 'A history of the term "moral hazard"', Journal of Risk and Insurance, 79(4), 1051-1075.

Sandler, R. (2012), 'Clunkers or junkers? Adverse selection in a vehicle retirement program', American Economic Journal: Economic Policy, 4(4), 253-281.

Schneider, L. (2009), 'Assessing the additionality of CDM projects: Practical experiences and lessons learned', Climate Policy, 9(3), 242-254.

Schneider, L. and Kollmuss, A. (2015), 'Perverse effects of carbon markets on HFC-23 and $\mathrm{SF}_{6}$ abatement projects in Russia', Nature Climate Change, 5, 1061-1063.

Siebert, H. (2008), Economics of the Environment. $6^{\text {th }}$ Edition. Springer, Berlin.

Strand, J. and Rosendahl, K.E. (2012), 'Global emissions effects of CDM projects with relative baselines', Resource and Energy Economics, 34(4), 533-548.

Taylor, L. (2015), 'Greg Hunt hasn't a lot to show for \$660m spent on reducing greenhouse emission', The Guardian, 1 May, http://www.theguardian.com/environment/2015/may/01/greg-hunt-660m-spent-reducinggreenhouse-emissions.

Thampapillai, D.J. and Sinden, J.A. (2013), Environmental Economics: Concepts, Methods and Policies. $2^{\text {nd }}$ Edition. Oxford University Press, South Melbourne, Australia.

Tietenberg, T. and Lewis, L. (2012), Environmental \& Natural Resource Economics. $9^{\text {th }}$ Edition. Pearson, Upper Saddle River, NJ.

Tisdell, C.A. (2005), Economics of Environmental Conservation. $2^{\text {nd }}$ Edition. Edward Elgar, Cheltenham, UK.

van Benthem, A. and Kerr, S.C. (2013), 'Scale and transfers in international emissions offset programs', Journal of Public Economics, 107, 31-46.

van Kooten, G.C., Bogle, T.N. and de Vries, F.P. (2015), 'Forest carbon offsets revisited: Shedding light on darkwoods', Forest Science, 61(2), 370-380. 
Victor, D. (2009), 'Plan B for Copenhagen', Nature, 461, 342-344.

Wara, M. (2008), 'Measuring the Clean Development Mechanism's performance and potential', UCLA Law Review, 55(6), 1759-1803.

Wills, I. (2006), Economics and the Environment: A Signalling and Incentives Approach. $2^{\text {nd }}$ Edition. Allen \& Unwin, Crows Nest, Australia.

Wood, T., Blowers, D. and Moran, G. (2016). Climate Phoenix: A Sustainable Australian Climate Policy. Grattan Institute Report No. 2016-6, April. 